\title{
COMPARATIVE ANALYSIS OF THE ANTI-PROLIFERATIVE EFFECT OF NATURAL PRODUCTS CATECHIN HYDRATE AND EPIGALLOCATECHIN (EXTRACT) APPLIED ON LEUKEMIA LYMPHOCYTES
}

\author{
Donika Ivanova ${ }^{*}$, Zvezdelina Yaneva
}

Trakia University, Faculty of Veterinary Medicine, Department of Pharmacology, Animal Physiology and Physiological Chemistry, Chemistry Unit, Stara Zagora, Bulgaria

\begin{abstract}
Cancer diseases are a problem with worldwide importance. However, the the lack of selectivity and induction of toxic side effect during conventional cancer therapy continue to provoke the search of innovative treatment approaches. Recent scientific results have reported for synergistic effect between combination of natural products and chemotherapeutic drugs. In this aspect, flavonoids, which are widely distributed in nature, are well known to exhibit numerous biological activities, including antioxidant, antibacterial, anti-inflammatory, anti-viral and anti-cancer effects and may also, play a role in cancer prevention. In the present study, the effects of low concentrations of catechin hydrate and epigallocatechin, Acacia Catechu spay-dried extract, on cell viability of leukemia lymphocytes were investigated and compared, in order to provide an experimental basis for their future incorporation into newly-synthesized biopolymer particles.
\end{abstract}

Keywords: Cancer, natural products, epigallocatechin, catechin hydrate, cell viability

\section{INTRODUCTION}

In recent years, the goal in cancer therapy is to achieve selectivity between damaged and healthy cells. The fact that the toxic side effect of applied conventional anticancer drugs is due to induction of oxidative stress and disruption of redox homeostasis in normal (healthy) cells and tissues [1], [2], provoke researchers to search for a new flexible approach in cancer therapy. Our previous results have shown that the combination of natural substances, most of them with redox modulation properties, with conventional or new generation anticancer drugs have shown synergistic cytotoxic effect specific to cancer cells and decrease of oxidative stress in normal cells [3-6]. Flavonoids, a group of natural substances with various phenolic structures, have attracted considerable scientific and therapeutic interest. These compounds are widely distributed in nature and have diverse multiple biological activities, including antioxidant, antimicrobial, anti-inflammatory, antiviral, antiallergic and anticancer properties [7,8]. Different epidemiological studies have demonstrated decreased risk of cancer diseases, after consumption of foods and drinks, which contain flavonoids (vegetables, fruits and tea) $[3,9,10]$. The natural products catechin and epigallocatechin, which belong to the flavonoids group, have the ability to scavenge free radicals, reduce the rate of LDL oxidation, inhibit lipid peroxidation and participate in modulation of the immune response in several biological systems [11-14]. In the present study, the effects of Acacia Catechu spray-dried epigallocatechin extract and catechin hydrate, applied in low concentrations ( $\mu \mathrm{mol} / \mathrm{L})$, on cell viability of cancer cell line were investigated and compared. The aim is to provide an experimental basis for their future incorporation into chitosan carriers, as well as experimental results for their possible clinical application in cancer therapy.

\section{MATERIALS AND METHODS}

\subsection{Materials}

The pure substance catechin hydrate was purchased from Sigma-Aldrich, Steinheim, Germany and the natural product - powdered epigallocatechin extract -from Acacia Catechu was supplied from North India. The experiments were performed on leukemia lymphocytes (Jurkat; RIKEN Bioresource Center, Saitama, Japan) derived from patients with acute lymphoblastic leukemia

\subsection{Cells and treatment protocol}

The cells were cultured in RPMI-1640 medium (Sigma-Aldrich, Steinheim, Germany), supplemented with 10\% heat-inactivated fetal bovine serum (Gibco, Auckland, New Zealand) and antibiotics (100 U/ml penicillin and $100 \mu \mathrm{g} / \mathrm{ml}$ streptomycin) (Gibco) in a humidified atmosphere at $37^{\circ} \mathrm{C}$ with $5 \% \mathrm{CO}_{2}$. All cells were collected by centrifugation ( $1000 \times \mathrm{g}$ for $10 \mathrm{~min}$ ) and replaced in a fresh medium without antibiotics, before treatment. The studied compounds catechin hydrate and epigallocatechin (extract) were dissolved in dimethyl sulfoxide (DMSO; suitable for cell cultures; Sigma-Aldrich). The final concentration of DMSO in

\footnotetext{
*donika georgiewa@abv.bg
} 
the cell suspension did not exceed 1\%. At this concentration, DMSO did not influence cell viability. The cells $\left(1 \times 10^{6}\right.$ cells $\left./ \mathrm{ml}\right)$ were incubated with catechin hydrate and epigallocatechin (extract) at the following concentrations: $0.5 \mu \mathrm{M}, 1 \mu \mathrm{M}, 10 \mu \mathrm{M}, 20 \mu \mathrm{M}$ and $50 \mu \mathrm{M}$.

\subsection{Cell proliferation and viability assays}

MTT assay (Sigma-Aldrich) was used for detection of cell viability and proliferation activity. $50 \mu \mathrm{L}$ of MTT (3-(4,5-dimethylthiazol-2-yl)-2,5-diphenyltetrazolium bromide) was added to $50 \mu \mathrm{L}$ cells in fresh medium (place in 96-well plates) and incubated at $37{ }^{\circ} \mathrm{C}$ for 1 hour. After incubation, $150 \mu \mathrm{L}$ of MTT solvent was added to each well and incubated for $15 \mathrm{~min}$ in the dark with shaking to fully dissolve MTT formazan. The absorbance at $590 \mathrm{~nm}$ was recorded immediately after that, using a microplate reader (TECAN Infinite $\mathbb{R}$ M100o, Austria).

\subsection{Statistical analysis}

All results are expressed as mean \pm standard deviation from two independent experiments with three parallel samples for each experiment $(n=6)$. Comparisons between the groups were performed using Student's t-test. A value of $\mathrm{p}<0.05$ was considered as significant.

\section{RESULTS AND DISCUSSION}

\subsection{Determination of anti-proliferative activity of} catechin hydrate and epigallocatechin (extract)

After incubation (24, 48 and 72 hours) with different concentrations of catechin hydrate or epigallocatechin (extract), the cell viability of Jurkat cancer cell line was measured using MTT assay. The results of the effect of catechin hydrate or epigallocatechin (extract), in low concentration ranges (from $0.5 \mu \mathrm{M}$ to $50 \mu \mathrm{M}$ ) on the proliferative activity of leukemia lymphocytes, were presented in Figures 1 and 2. The effect of each concentration of the studied compounds was calculated as a percentage of control (untreated cells), where the proliferation activity of the cells was considered $100 \%$. The data demonstrated slight decrease of cell viability of leukemia lymphocytes (up to 20\%) after treatment with the studied compounds. Relatively identical effect of both natural compounds applied at all concentrations, after 48 hours incubation was observed. Enhancement of cell viability of Jurkat cells after 24- and 72-hours incubation with epigallocatechin (extract), applied at $20 \mu \mathrm{M}$ and $50 \mu \mathrm{M}$ concentrations, was registered. Whilst decreased proliferative activity in the case of cells treated with catechin hydrate at the stated working conditions was observed

Up-to-date scientific studies also confirm the antiproliferative activity of catechins. Rayen et al. (2017) investigated a wide concentration range of catechins (from $100 \mathrm{nM}$ to $100 \mu \mathrm{M}$ ) and their results indicated significant reduction of MTT by catechin at concentration of $100 \mu \mathrm{M}$. It was also established that epigallocatechin-3-gallate exhibited significantly higher cytotoxic activity at a dose $\geq 10 \mu \mathrm{M}$ as compared to other studied compounds at these conditions [18]. The experimental evidence, presented by Kürbitz et al. (2011) demonstrated that epigallocatechin gallate, catechin gallate and epicatechin gallate, which are minor components of green tea, inhibited proliferative activity of human pancreatic ductal adenocarcinoma (PDAC) cells in a dose- and time-dependent manner [15]. On the other side, there is data which indicated that applied in high concentrations (200 $\mu \mathrm{M}$ and 400 $\mu \mathrm{M})$ on non-cancer lymphoid cell line, flavonoids did not modify cell viability in both resting and stimulated lymphocytes after a $24 \mathrm{~h}$ incubation period [16].

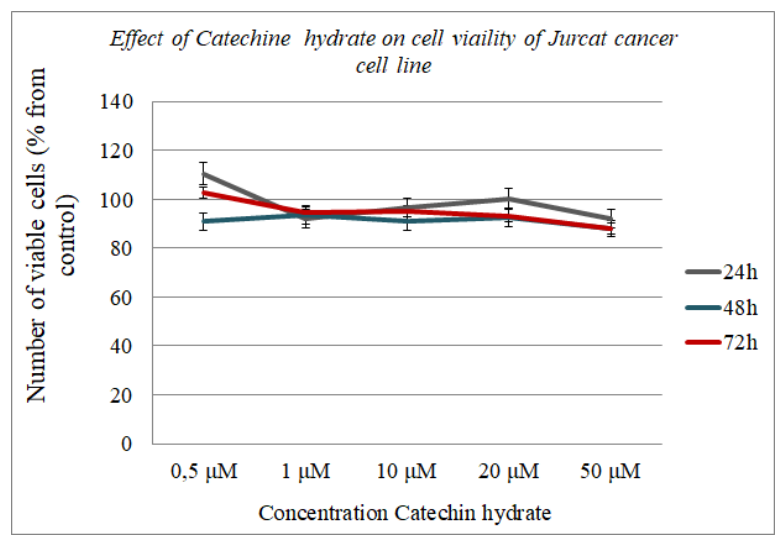

Figure 1. Anti-proliferative effect of catechin hydrate on Jurkat cancer cell line at different incubation time. (Data are presented as mean \pm SD from six values at each concentration)

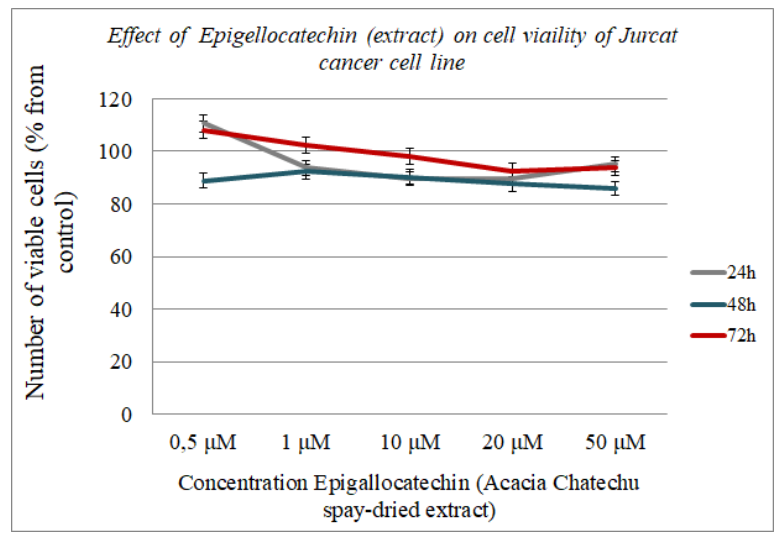

Figure 2. Anti-proliferative effect of epigallocatechin extracted from Acacia Catechu on Jurkat cancer cell line at different incubation time. (Data are presented as mean \pm SD from six values at each concentration)

\subsection{Comparative analysis of the effect of catechin hydrate and epigallocatechin (extract) on cell viability of leukemia lymphocytes}

The comparative analysis of cell viability of leukemia lymphocytes, treated with catechin hydrate or epigallocatechin (extract) after 48 hours incubation, was performed. The obtained results are presented in Figure 3. Similar anti-proliferative activity (up to 20\% in all applied concentrations) of both studies compounds, compared to the control, was observed. 


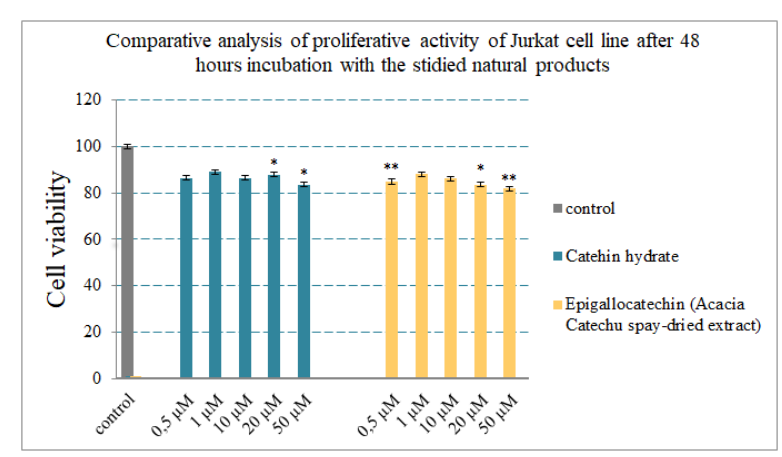

Figure 3. Comparative analysis of anti-proliferative activity of catechin hydrate (in blue) and epigallochatechin extracted from Acacia Catechu (in yellow) on Jurkat cell line after 48 hours incubation time. The grey color indicates untreated cells (control). (Mean $\pm \mathrm{SD}, \mathrm{n}=6)$. Two levels of significances were considered: $\mathrm{p}<0.05\left(^{*}\right)$ and $\mathrm{p}<0.01\left({ }^{* *}\right)$.Significant differences in the groups treated with catechin hydrate and epigallocatechin, extracted from Acacia Catechu, as compared to the control (untreated cells) were indicated.

The similarity of the anti-proliferative effect of catechin hydrate and epigallocatechin (extract) could be due to the same molecular mechanism of action of the studied compounds. It is proposed that the antiinflammatory and immunomodulatory activity of flavonoids is due to regulation of NF-kB signaling (nuclear factor kappa-light-chain-enhancer of activated B cells) [11]. In this aspect, Mackenzie et al. (2004) established that flavonoids, including catechin, were implicated in the modulation of phorbol 12-myristate 13-acetate (PMA)-induced NF- $\mathrm{BB}$ activation in Jurkat $\mathrm{T}$ cells by the regulation of $\mathrm{IL}-2$ at the level of transcription. The obtained results displayed that preincubation for 24 hours with catechin, applied in different concentration range (from $1.7 \mu \mathrm{M}$ to 17.2 $\mu \mathrm{M}$ ), decreased PMA-induced NF- $\kappa \mathrm{B}$ binding activity, through a direct interaction of flavonoids with NF-kB proteins, inhibition of the binding of active NF- $\kappa B$ to $\kappa \mathrm{B}$ sites and the transactivation of the NF- $\mathrm{BB}$-driven gene IL-2 [11]. Thus, it has been considered that the intracellular mechanism of action of catechins is associated with an influence on the immune response by modulating NF- $\mathrm{KB}$ activation. In this aspect, the study of Suhail et al. (2019) presented a corroboration of the impact of flavonoids on the specific for cancer cells NF-kB molecular pathway. The provided results form molecular docking demonstrated that epicatechin, epigallocatechin, epicatechin gallate and epigallocatechin gallate block NF-kB binding site through interaction with its different amino acids residues. The scientific team reported the formation of protein-ligand interaction between NF-kB and the studied flavonoids [17]. An earlier study demonstrated that catechin gallate and epicatechin gallate inhibited the proliferation of human pancreatic ductal adenocarcinoma (PDAC) cells due to influence of modulation on NF-kB activity. In the same report, the evidences outlined that epicatechin gallate inhibited TNFa-induced activation of NF-kB, the consequent secretion of pro-inflammatory and invasion of promoting proteins such as IL-8 and the urokinase plasminogen activator (uPA). In this regard, due to the observed anti-inflammatory potential of flavonoids, especially of epicatechin gallate, they could be applied as supplements to anticancer therapies [15].

\section{CONCLUSION}

In summary, the results of the present study provide evidence that catechin hydrate and epigallocatechin, extracted from Acacia Chatechu, applied at low concentrations $(\mu \mathrm{mol} / \mathrm{L})$, displayed slight decrease of cell viability of leukemia lymphocytes. Thus, future studies of the potential of chitosan/epigallocatechin-loaded chitosan-based carriers, in combination with chemotherapeutic drugs could present essential data for the probable benefits of their application in cancer therapy. However, the in vitro anticancer and anti-inflammatory activity mechanisms of such bioflavonoid-biopolymer carrier formulations on different cancer cell lines need to be precisely investigated.

Acknowledgements: The paper is a part of the research done within the projects: Bulgarian Ministry of Education and Science under the National Research Program "Healthy Foods for a Strong Bio-Economy and Quality of Life" approved by DCM \# 577/ 17.08.2018 and Scientific Project 1/2019, FVM, Trakia University, Bulgaria (granted to D.I.).

\section{REFERENCES}

1. P. Angsutararux, S. Luanpitpong, S. Issaragrisil, "Chemotherapy-induced cardiotoxicity: Overview of the role of oxidative stress," Oxid. Med. Cell Longev., vol. 2015, art. ID 795602, pp. 1-13, Sep. 2015. http://doi.org/10.1155/2015/795602 PMid: 26491536

2. S. Jaiman, A.K. Sharma, K. Singh, D. Khanna. "Signaling mechanisms involved in renal pathological changes during cisplatin-induced nephropathy," Eur. J. Clin. Pharmacol. vol. 69 no. 11, pp. 1863-1874, Nov. 2013. http://doi.org/10.1007/s00228-013-1568-7 PMid: 23929259

3. D. Ivanova, Zh. Zhelev, S. Semkova, I. Aoki, R. Bakalova, "Resveratrol modulates the redox-status and cytotoxicity of anticancer drugs by sensitizing leukemic lymphocytes and protecting normal lymphocytes," Anticancer Res., vol. 39 no. 7, pp. 3745-3755, Jul 2019.

http://doi.org/10.21873/anticanres.13523

PMid: 31262901

4. D. Ivanova, Zh. Zhelev, D. Lazarova, P. Getsov, R. Bakalova I. Aoki, "Vitamins C and $\mathrm{K}_{3}$ : a powerful redox system for sensitizing leukemia lymphocytes to everolimus and barasertib," Anticancer Res., vol. 38 no. 3, pp. 1407-1414, Mar. 2018. http://doi.org/10.21873/anticanres.12364 PMid: 29491065

5. Zh. Zhelev, D. Ivanova, D. Lazarova, I. Aoki, R. Bakalova, T. Saga, "Docosahexaenoic acid sensitizes leukemia lymphocytes to baraserib and everolimus by ROS-dependent mechanism without affecting the level of ROS and viability of normal lymphocytes, Anticancer Res., vol. 36, no. 4, pp. 1673-1682, Apr. 2016. PMid: 27069145

6. Zh. Zhelev, D. Ivanova, R. Bakalova, I. Aoki, T. Higashi, "Synergistic Cytotoxicity of Melatonin and Newgeneration Anticancer Drugs Against Leukemia Lymphocytes but not Normal Lymphocytes," Anticancer Res., vol. 37, no. 1, pp. 149-159, Jan. 2017. http://doi.org/10.21873/anticanres.11300 PMid: 28011485

7. C.R. da Silva, J.B. de Andrade Neto, R. de Sousa Campos, N.S. Figueiredo, L.S. Sampaio, 
H.I.F. Magalhres, B.C. Cavalcanti, D.M. Gaspar, G.M. de Andrade, I.S.P. Lima, G.S. de Barros Viana, M.O. de Moraes, M.D.P. Lobo, T.B. Grangeiro, H.V.N. Júniora, "Synergistic effect of the flavonoid catechin, quercetin, or epigallocatechin gallate with fluconazole induces apoptosis in Candida tropicalis resistant to fluconazole," Antimicrob. Agents and Chemother., vol. 58, no. 3, pp. 1468-1478, Mar. 2014. http://doi.org/10.1128/AAC.00651-13 PMid: 24366745

8. J.H. Jeong, J.Y. An, Y.T. Kwon, J.G. Rhee, Y.J. Lee, "Effects of low dose quercetin: Cancer cell-specific inhibition of cell cycle progression, J. Cell Biochem., vol. 106, no. 1, pp. 73-82, Jan. 2009. http://doi.org/10.1002/jcb.21977 PMid: 19009557

9. N.P. Bondonno, F. Dalgaard, C. Kyre, K. Murray, C.P. Bondonno, J.R. Lewis, K.D. Croft, G. Gislason, A.Scalbert, A. Cassidy, A. Tjenneland, K. Overvad, J.M. Hodgson, "Flavonoid intake is associated with lower mortality in the danish diet cancer and health cohort, " Nat Commun., vol. 10, no. 3651, pp. 1-10, Aug. 2019.

http://doi.org/10.1038/s41467-019-11622-x PMid: 31409784

10. C. Rodriguez-Garcia, C. Sánchez-Quesada, J.J. Gaforio, "Dietary flavonoids as cancer chemopreventive agemts: an update review of human studies," MDPI Antioxidants, vol. 8, no. 137, pp. 1-23, May 2019. http://doi.org/10.3390/antiox8050137 PMid: 31109072

11. G.G. Mackenzie, F. Carrasquedo, J.M. Delfino, C.L. Keen, C.G. Fraga, P.I. Oteiza, "Epicatechin, catechin, and dimeric procyanidins inhibit PMAinduced NF- $\mathrm{BB}$ activation at multiple steps in Jurkat T cells," FASEB J., vol. 18, no. 1, pp. 167-169, Jan. 2004. http://doi.org/10.1096/fj.03-0402fje PMID: 14630700

12. S.B. Lotito, C.G. Fraga, "(+)-Catechin prevents human plasma oxidation," Free Radic. Biol. Med., vol. 24, no. 3, pp. 435-441, Feb. 1998.

http://doi.org/10.1016/s0891-5849(97)00276-1 PMid: 9438556
13. S. B. Lotito, L. Actis-Goretta, M.L. Renart, M. Caligiuri, D. Rein, H.H. Schmitz, F.M. Steinberg, C.L. Keen, C.G. Fraga, "Influence of oligomer chain length onthe antioxidant activity of procyanidins," Biochem. Biophys. Res. Commun., vol. 276, no. 3, pp. 945-951, Oct. 2000.

http://doi.org/10.1006/bbrc.2000.3571 PMid: 11027573

14. C. Sanbongi, N. Susuki, T. Sakane, "Polyphenols in chocolate, which have antioxidant activity, modulate immune functions in humans in vitro," Cell. Immunol., vol. 177, no. 2, pp. 129-136, May 1997. http://doi.org/10.1006/cimm.1997.1109 PMid: 9178639

15. C. Kürbitz, D. Heise, T. Redmer, F. Goumas, A. Arlt, J. Lemke, G. Rimbach, H. Kalthoff, A. Trauzold, "Epicatechin gallate and catechin gallate are superior to epigallocatechin gallate in growth suppression and antiinflammatory activities in pancreatic tumor cells," Cancer Sci, vol. 102, no. 4, 728-734, Apr. 2011. http://doi.org/10.1111/j.1349-7006.2011.01870.x PMid: 21241417

16. E. Ramiro, A. Franch, C. Castellote, C.Andrès-Lacueva, M. Izquierdo-Pulido, M. Castell, "Effect of Theobroma cacao flavonoids on immune activation of a lymphoid cell line", British J. of Nutrition, vol. 93, no 6, 859-866, Jun 2005 . http://doi.org/10.1079/BJN20051443 PMID: 16022755

17. M. Suhail, A. Parveen, A. Husain, M. Rehan, "Exploring inhibitory mechanisms of green tea catechins as inhibitors of a cancer therapeutic target, Nuclear Factor-kB (NF-kB)", Biosci. Biotech. Res. Asia, vol. 16, no 4, 515-723, December 2019. http://doi.org/10.13005/bbra/2787

18. V.L. Rayen, P.E. Porporato, P. Danhier, T. Vazeille, M.C.N.M. Blackman, B.H. May, P. Niebes, P. Sonveaux, "(+)-Catechin in a 1:2 complex with lysine inhibits cancer cell migration and metastatic take in mice," Front. Pharmacol., vol.8, Dec. 2017. http://doi.org/10.3389/fphar.2017.00869 PMid: 29255416 